\title{
Correction to: Single-cell transcriptome conservation in a comparative analysis of fresh and cryopreserved human skin tissue: pilot in localized scleroderma
}

Emily Mirizio ${ }^{1}$, Tracy Tabib² ${ }^{2}$ Xinjun Wang ${ }^{3}$, Wei Chen ${ }^{3}$, Christopher Liu', Robert Lafyatis ${ }^{2}$, Heidi Jacobe ${ }^{4+}$ and Kathryn S. Torok ${ }^{1,25^{*}+}$

Correction to: Arthritis Res Ther (2020) 22:263

https://doi.org/10.1186/s13075-020-02343-4

Following publication of the original article [1], the authors reported an error in one of the author's name. The 3rd author should be Xinjun Wang, as this was incorrectly given as Xiao Wang by the corresponding author during proofing stage.

The original article has been corrected.

\begin{abstract}
Author details
'Division of Rheumatology, Department of Pediatrics, Children's Hospital of Pittsburgh, University of Pittsburgh, Pittsburgh, PA, USA. ${ }^{2}$ Division of Rheumatology, Department of Medicine, University of Pittsburgh, Pittsburgh, PA, USA. ${ }^{3}$ Division of Pediatric Pulmonary Medicine, UPMC Children's Hospital of Pittsburgh, University of Pittsburgh, Pittsburgh, PA, USA. ${ }^{4}$ Department of Dermatology, University of Texas Southwestern Medical Center, Dallas, TX, USA. ${ }^{5}$ University of Pittsburgh Medical Center Children's Hospital of Pittsburgh Faculty Pavilion, 3rd floor, Office 31174401 Penn Avenue, Pittsburgh, PA 15237, USA.
\end{abstract}

Published online: 06 April 2021

\section{Reference}

1. Mirizio E, Tabib T, Wang X, et al. Single-cell transcriptome conservation in a comparative analysis of fresh and cryopreserved human skin tissue: pilot in localized scleroderma. Arthritis Res Ther. 2020;22:263 https://doi.org/10.11 86/s13075-020-02343-4.

The original article can be found online at https://doi.org/10.1186/s13075020-02343-4.

*Correspondence: Kathryn.Torok@chp.edu

${ }^{\dagger}$ Heidi Jacobe and Kathryn S. Torok are co-senior authors.

'Division of Rheumatology, Department of Pediatrics, Children's Hospital of Pittsburgh, University of Pittsburgh, Pittsburgh, PA, USA

${ }^{2}$ Division of Rheumatology, Department of Medicine, University of Pittsburgh, Pittsburgh, PA, USA

Full list of author information is available at the end of the article

(c) The Author(s). 2021 Open Access This article is licensed under a Creative Commons Attribution 4.0 International License, which permits use, sharing, adaptation, distribution and reproduction in any medium or format, as long as you give appropriate credit to the original author(s) and the source, provide a link to the Creative Commons licence, and indicate if changes were made. The images or other third party material in this article are included in the article's Creative Commons licence, unless indicated otherwise in a credit line to the material. If material is not included in the article's Creative Commons licence and your intended use is not permitted by statutory regulation or exceeds the permitted use, you will need to obtain permission directly from the copyright holder. To view a copy of this licence, visit http://creativecommons.org/licenses/by/4.0/ The Creative Commons Public Domain Dedication waiver (http://creativecommons.org/publicdomain/zero/1.0/) applies to the data made available in this article, unless otherwise stated in a credit line to the data. 